\title{
Pollination, Crop Productivity, and Arthropod and Bird Communities Are Marginally Impacted by Border Vegetation in Highbush Blueberry Production
}

\author{
Olivia M. Smith ${ }^{1}$, Beverly Gerdeman ${ }^{2}$, Matthew Arrington ${ }^{3}$, \\ Hollis Spitler ${ }^{2}$, and Lisa Wasko DeVetter ${ }^{4}$
}

AdDitional index wORDs. Apis mellifera, bird damage, ecosystem service, insect pests, pollinator habitat, Vaccinium corymbosum

Summary. Herbaceous flowering or woody plant borders adjacent to highbush blueberry (Vaccinium corymbosum) fields have the potential to benefit both native pollinators and species of predatory and parasitic arthropods and birds that feed on key highbush blueberry pests, such as spotted wing drosophila [SWD (Drosophila suzukii)]. However, they may also draw pollinators away from the crop, serve as overwintering and/or refugia sites for SWD, and increase the abundance of wild birds that feed on fruit and harbor foodborne pathogens. The objective of this 1year, observational study was to explore the potential impacts of border vegetation adjacent to commercial highbush blueberry fields on pollination, crop productivity, and arthropod and bird communities within the Pacific Northwest region in the United States. The study included three highbush blueberry cultivars (Duke, Draper, and Liberty), and three field border vegetation treatments: 1) woody perennial vegetation; 2) herbaceous vegetation; and 3 ) medium-height grasses (control). There was one border treatment per cultivar for a total of nine sites. No cultivar effects nor interactions for any of the variables were detected, so results were combined across cultivars. No differences in pollinator abundance, pollinator visitation rates, estimated yield, berry weight, and seed number were observed across the treatments. Herbaceous borders had more natural enemies than the woody perennial borders, but both were similar to the control. This trend is attributed to higher abundances of parasitic wasps (suborder Apocrita) in the herbaceous and control borders compared with the woody perennial borders. Increased abundances of aphids (family Aphididae), a host for parasitic wasps, likely influenced these results. Differences in predatory arthropods were not observed. Insect abundances were overall low in all field sites measured in this study, likely influenced by SWD insecticide applications. There were no differences in total wild bird density by treatment except for barn swallows (Hirundo rustica), which were greatest in the control treatment. Overall, the border treatments evaluated in this study had smallto-negligible impacts on the measured variables, and there was no clear crop production benefit. Additionally, none of the investigated border treatments negatively impacted highbush blueberry production. Taken together, border vegetation treatments can provide benefits such as reducing pesticide drift, deterring trespassers, and serving as a windbreak; but any potential benefits from a pollination or biocontrol aspect are likely diminished due to current SWD management practices.

W ithin the Pacific Northwest (PNW) region in the United States, Washington and Oregon are national leaders in highbush blueberry (Vaccinium corymbosum) production. In 2019, the PNW produced $\approx 318.8$ million pounds of fruit, which represented $\approx 46 \%$ of total national production and was valued at $\$ 287.5$ million (U.S. Department of Agriculture, National Agricultural Statistics Service, 2020). Despite the industry's success, improving pollination and fruit set is a shared goal among growers in the PNW. Pollination is particularly challenging for growers west of the Cascade Range, where cool and rainy conditions during the bloom period are unfavorable for pollination by honeybees (Apis mellifera). The morphology of highbush blueberry flowers and low nectar reward also limits honeybee pollination of highbush blueberry (Courcelles et al., 2013). Rented hives of honeybees are the primary method growers use to pollinate their fields, but pollination is frequently inadequate. DeVetter et al. (2016) found honeybee visitations in western Washington are below the recommended density of four-to-eight honeybees per bush during the warmest part of the day, suggesting inadequate pollination is a constraint to achieving maximum yields and productivity (Isaacs et al., 2016).

Previous research has shown insectary strips or flowering borders can promote pollination in highbush blueberry by increasing pollinator richness and abundance (Blaauw and Isaacs, 2014). Blaauw and Isaacs (2014) compared highbush blueberry fields adjacent to perennial wildflower borders containing plant species known to be attractive to bees, to fields adjacent to mowed grass borders in Michigan. The 15 wildflower species used in their study were native to Michigan [seed obtained from Michigan Wildflower Farm, Portland, MI (see Tuell et al., 2008 for a list of the wildflower species used)] and had a combined bloom period that extended from May through October. They observed an increase in the abundance of wild bees and syrphid flies (clade Anthophila and family Syrphidae, respectively), while honeybee populations were the same between wildflower and grass borders. Furthermore, fruit set, berry weight, and seed number per berry were greater among highbush blueberry plants adjacent to wildflowers, which led to increased yield and revenue that exceeded the cost of wildflower establishment and maintenance. Wild bee abundance has also been observed to be positively correlated with proximity to seminatural habitat at local and landscape levels in

\begin{tabular}{llll}
\hline $\begin{array}{l}\text { Units } \\
\text { To convert U.S. to SI, } \\
\text { multiply by }\end{array}$ & U.S. unit & SI unit & $\begin{array}{l}\text { To convert SI to U.S., } \\
\text { multiply by }\end{array}$ \\
\hline 0.3048 & $\mathrm{ft}$ & $\mathrm{m}$ & 3.2808 \\
2.54 & inch $(\mathrm{es})$ & $\mathrm{cm}$ & 0.3937 \\
0.4536 & $\mathrm{lb}$ & $\mathrm{kg}$ & 2.2046 \\
1.6093 & $\mathrm{mile}(\mathrm{s})$ & $\mathrm{km}$ & 0.6214 \\
28.3495 & $\mathrm{Oz}$ & $\mathrm{g}$ & 0.0353 \\
$\left({ }^{\circ} \mathrm{F}-32\right) \div 1.8$ & ${ }^{\circ} \mathrm{F}$ & ${ }^{\circ} \mathrm{C}$ & $\left({ }^{\circ} \mathrm{C} \times 1.8\right)+32$
\end{tabular}


both Michigan and British Columbia, Canada (Gibbs et al., 2016). Increased abundance of natural enemies, including predaceous arthropods, has also been observed when highbush blueberries are grown adjacent to wildflower borders (Blaauw and Isaacs, 2015). These findings suggest similar benefits on pollination and biocontrol may be achieved through border vegetation in PNW highbush blueberry fields.

Despite these positive findings, there is concern regarding the potential negative aspects of border vegetation on highbush blueberry production. Arborvitae (Thuja occidentalis) is a popular hedgerow species bordering highbush blueberry fields in the PNW and functions to prevent pesticide drift onto adjacent properties. The primary insect pest targeted by spray programs is spotted wing drosophila [SWD (Drosophila suzukii)], a direct pest whose larvae feed on developing fruit. Infestations of SWD lead to unsellable fruit or fruit that is downgraded based on poor quality. SWD will overwinter in evergreen vegetation (Haviland et al., 2016) and have been recovered in arborvitae (B. Gerdeman, personal observation), raising concern that border vegetation may serve as overwintering sites for SWD and

Received for publication 16 Sept. 2020. Accepted for publication 13 Nov. 2020.

Published online 23 December 2020.

${ }^{1}$ Department of Entomology, University of Georgia, 120 Cedar Street, 413 Biological Sciences Building, Athens, GA 30602

${ }^{2}$ Department of Entomology, Washington State University Northwestern Washington Research and Extension Center, 16650 State Route 536, Mount Vernon, WA 98273

${ }^{3}$ Department of Plant and Wildlife Sciences, Brigham Young University, 5108 LSB / 108 LSGH, Provo, UT 84602

${ }^{4}$ Department of Horticulture, Washington State University Northwestern Washington Research and Extension Center, 16650 State Route 536, Mount Vernon, WA 98273

Funding for this project came from Washington State University's BioAg Program. This work was also supported by the U.S. Department of Agriculture, National Institute of Food and Agriculture Hatch project 1014919.

We would like to acknowledge the assistance of William (Bill) Snyder, Sean Watkinson, Kerri Scott, and Clara TeVelde. We are also grateful for Carol Miles very careful internal review.

L.W.D. is the corresponding author. E-mail: lisa. devetter@wsu.edu.

This is an open access article distributed under the CC BY-NC-ND license (https://creativecommons.org/ licenses/by-nc-nd/4.0/).

https://doi.org/10.21273/HORTTECH04735-20

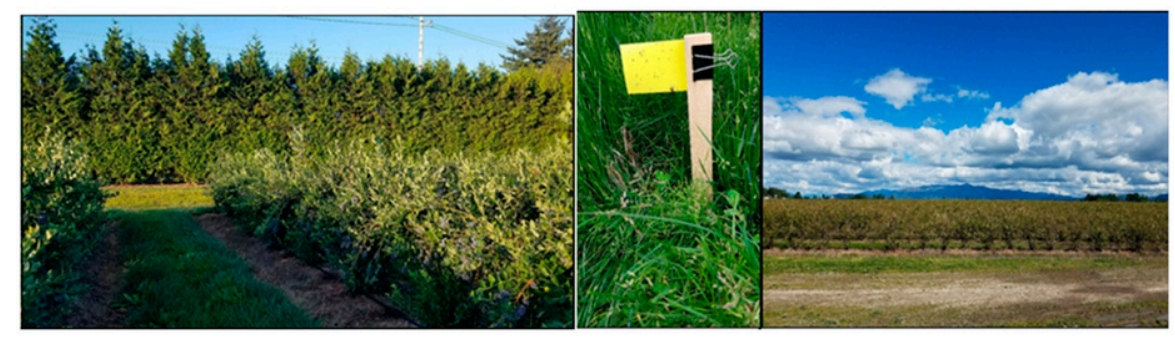

Fig. 1. Border vegetation treatments adjacent to highbush blueberry plantings studied in 2017 include the following: 1 ) woody perennial vegetation (furthest left), 2) herbaceous vegetation (center), and 3) control of medium-height grasses (furthest right). Photos are by L.W. DeVetter.

encourage their establishment. Additionally, native flowering plants bordering highbush blueberry fields may supplement SWD nutrition, particularly survivorship of late dormant adult SWD (Tochen et al., 2016), thereby potentially enhancing establishment and increasing pest populations earlier in the season.

Another concern is that border vegetation could provide habitat and increase abundances of birds that feed on and damage blueberries [Vaccinium sp. (Anderson et al., 2013)], as well as harbor foodborne pathogens (e.g., human-pathogenic strains of Escherichia coli and Salmonella sp.) that could be transmitted to humans if birds defecate in fields (Nielsen et al., 2004; Smith et al., 2020). Conversely, border vegetation could increase habitat for insectivorous birds that contribute to biological control of pest insects (Boesing et al., 2017), and of raptors [order Accipitriformes (e.g., hawks) and order Falconiformes (e.g., kestrels)] that kill or scare away pest birds (Shave et al., 2018; Symondson et al., 2002). Overall, evidence from some studies suggests that border vegetation can increase highbush blueberry yields by promoting pollination and biocontrol, while other studies indicate there may be negative aspects that reduce crop yields and quality as well as endanger food safety. Therefore, our study assessed the impact of border vegetation adjacent to commercial highbush blueberry fields on pollination, overall crop productivity, and arthropod and bird communities within northwestern Washington.

\section{Materials and methods}

Nine commercially representative fields in northwestern Washington were selected for this observational study in 2017. Study field sites included three cultivars, Duke, Draper, and Liberty, and three field border vegetation treatments: 1) woody perennial vegetation, 2) herbaceous vegetation, and 3) mediumheight grasses (control) (Fig. l). Sites were selected due to distance from each other (a minimum of $2 \mathrm{~km}$ ), uniformity, similar management practices, and presence of our targeted treatments. The woody perennial vegetation consisted of a mixture of mature, woody perennial tree species including cedar (Cedrus sp.) and arborvitae, while the herbaceous vegetation included a mixture of unmowed grasses [e.g., meadow-grass and bluegrass (both Poa sp.) and quackgrass (Elymus sp.)] and flowering broadleaves [e.g., composites (family Asteraceae) and hairy willowherb (Epilobium birsutum)]. The control treatment also consisted of grasses maintained to a height of 4-10 inches and were predominately turf species that were intentionally planted [e.g., perennial rye grass (Lolium perenne) and bentgrass (Agrostis sp.)]. Cultivarborder treatments were replicated three times (nine field sites total). Vegetative borders were established naturally or by the growers, with no major roadways separating the borders from the highbush blueberry fields. The woody perennial and herbaceous vegetation treatments were along two sides of the highbush blueberry field perimeter, parallel and perpendicular to the highbush blueberry rows. The control surrounded all sides of the highbush blueberry field perimeter. To maintain consistency in our sampling strategy, the highbush blueberry field edge used for data collection was 9-15 $\mathrm{m}$ away from the border vegetation treatments. From this field edge, three $100-\mathrm{m}$ transects proceeding down three separate rows and toward 
the interior of the highbush blueberry planting were established for pollinator and crop productivity assessments. Each transect was $6 \mathrm{~m}$ apart; and within each transect, 10 representative highbush blueberry bushes $10 \mathrm{~m}$ apart from each other were tagged such that data collection occurred for the same 30 highbush blueberry bushes per site throughout the study. The first bush in the transect was $10 \mathrm{~m}$ from edge of the field and $19-25 \mathrm{~m}$ from the border.

Pollinator activity. Pollinator activity was measured as described by Courcelles et al. (2013), when plants were in $15 \%$ to $100 \%$ bloom at each field site, which occurred from April to May for the field sites in the study. Pollinator activity was measured for the 10 highbush blueberry bushes in each of the three transects on 3 separate days, which about coincided with the beginning, middle, and end of the bloom period per site. Measurement days were selected based on weather conditions that were conducive for pollinator activity and were similar for comparison purposes with our criteria set at $>55^{\circ} \mathrm{F}$ air temperature, low wind, full-to-partial sun, and no precipitation. On each sampling day, the number of flower visitations made by individual insects per bush within 1-min intervals was visually recorded and repeated three times per bush within $1 \mathrm{~d}$ from 1000 to $1600 \mathrm{HR}$. One individual counted visitations per bush within a transect and could achieve this because foliage was minimal, flowers were easily visible, and pollinator densities were low. Pollinator visitations were only enumerated when pollinators inserted their heads in the corolla, and nectar robbing activity was not recorded. Both pollinator species and relative abundances were also recorded during pollinator visitation counts.

Plant productivity. Yield per bush and berry weight were estimated from the 30 bushes per site used for pollinator activity assessments early in the harvest season to evaluate the effects of border treatment on crop productivity. Yield was determined through an estimation procedure that first required estimating berry number per bush. Berry number per bush was estimated by first recording the number of canes per bush and the average number of fruiting clusters per cane for two randomly selected canes per bush. Next, the average number of developing berries was recorded for the third cluster from the distal branch end from four representative branches located on two canes per bush. The equation for estimating berry number was as follows: berry number per bush $=($ cane number per bush $) \times($ average number of fruit clusters per cane) $\times$ (average berry number per cluster).

Average berry weight was then determined from 50 ripe berries sampled across each transect from both sides of the bushes. Estimated yield was subsequently calculated for each bush by multiplying average berry number per bush by average berry weight for the corresponding transect. Average seed number per berry was also determined, as the number of healthy, fertile seeds is indicative of fertilization and can serve as a proxy for effective pollination.

AbUNDANCES OF NATURAL ENEMY AND PEST ARTHROPOD SPECIES. Between 12 May and 31 Aug., the nine sites were sampled weekly for natural enemy [i.e., beneficial predatory arthropods and parasitic wasps (suborder Apocrita)] and pest arthropod species. Weekly sampling consisted of $30 \mathrm{~s}$ of vacuuming (D-Vac Vacuum Insect Net Model 122; RinconVitova Insectaries, Ventura, CA) an approximate $10-\mathrm{m}$ swath of representative border vegetation at each study site for a season total of 16 sampling times per site. Each sample was placed in a plastic bag, transported to the laboratory, and placed in a freezer at $-18{ }^{\circ} \mathrm{C}$. After $24 \mathrm{~h}$, samples were removed from the freezer, sorted as natural enemies or pests, identified to general taxonomic groups, and numbers of individuals in each group were recorded. Focal species were chosen based on their hypothesized roles on farms as natural enemies or crop-damaging pests. Natural enemies included parasitic wasps and predators [rove beetles (family Staphylinidae), ladybird beetles (family Coccinellidae), carabid beetles (family Carabidae), spiders (order Araneae), and lacewings (family Chrysopidae)]. Pests included aphids (family Aphididae) and thrips (order Thysanoptera).

To monitor populations of SWD, a single apple cider vinegar trap (Gerdeman et al., 2011) was placed in the border at each site. Trap height was dependent on the height of the border plants within each treatment. Traps were mounted on trees at 2 and $4 \mathrm{ft}$ in height in the woody perennial and herbaceous borders, respectively, and on 1.3-ft stakes in the control borders where no plants were available for attachment. Each week, trap contents were decanted into collection cups and transported to the laboratory for analyses and enumeration of individual SWD. Traps were refilled with fresh vinegar every week to keep them clean.

Avian assessments. During ripening and before harvest (July through August), wild bird abundance was estimated using a habitatbased point-count protocol (Smith et al., 2019). The number of count locations per site was proportional to field size, such that each point encompassed a $50-\mathrm{m}$ radius and points were $100 \mathrm{~m}$ apart to avoid double counting. Therefore, birds were observed at 2-10 points within highbush blueberry field sites. To assign point count locations at each field site, a start location was randomly selected at the field edge and points $100 \mathrm{~m}$ apart were laid out thereafter on a grid. Visual and auditory counts of individuals were made from sunrise $(0500$ $\mathrm{HR}$ ) to $0900 \mathrm{HR}$ and repeated twice per field site on 2 separate days. At each point, the number of individual birds seen or heard during a 10 -min period were identified. All surveys were conducted by one, trained observer. Observations were focused on species that are known to be present in northwestern Washington highbush blueberry fields and consume fruit (Billerman et al., 2020; Smith et al., 2019). In addition, species that have the potential to feed on insects [e.g., swallows (family Hirundinidae)], deter fruit-eating birds (e.g., raptors), and/or are potential human enteric pathogen reservoirs (Billerman et al., 2020; Smith et al., 2020) were included. In total, eight wild bird species were selected, but there was an insufficient number of observations to model red-tailed hawk (Buteo jamaicensis), european starling (Sturnus vulgarus), or american crow (Corvus brachyrhynchos) density. Therefore, density assessments focused on five focal bird species (Table 1). Diet guilds were classified following Wilman et al. (2014), and food pathogen 
Table 1. Guild and hypothesized role of five focal bird species surveyed in and adjacent to highbush blueberry fields in northwestern Washington in 2017 with different border vegetation treatments. Cultivars surveyed were pooled and included Duke, Draper, and Liberty.

\begin{tabular}{|c|c|c|c|}
\hline Species & Diet guild & Known reservoir ${ }^{z}$ & Hypothesized production role \\
\hline American robin (Turdus migratorius) & Omnivore & Salmonella sp..$^{\mathrm{y}}$ & Pest \\
\hline Barn swallow (Hirundo rustica) & Insectivore & $\begin{array}{l}\text { Campylobacter sp. }{ }^{\mathrm{x}} \\
\text { Escherichia coli }{ }^{\mathrm{w}} \\
\text { Salmonella } \text { sp. }^{\mathrm{v}}\end{array}$ & Beneficial \\
\hline Cedar waxwing (Bombycilla cedrorum) & Fruit-eating & Salmonella sp..$^{\mathrm{y}}$ & Pest \\
\hline House finch (Haemorhous mexicanus) & Grain-eating & Salmonella sp. ${ }^{\mathrm{u}}$ & Pest \\
\hline
\end{tabular}

${ }^{\mathrm{z}}$ See Smith et al. (2020) for a complete review of North American species.

${ }^{y}$ WHISPers database (U.S. Geological Survey, 2020).

${ }^{x}$ Hald et al. (2016).

${ }^{\text {w } K o b a y a s h i ~ e t ~ a l . ~(2009) . ~}$

"Skov et al. (2008).

"Gorski et al. (2011).
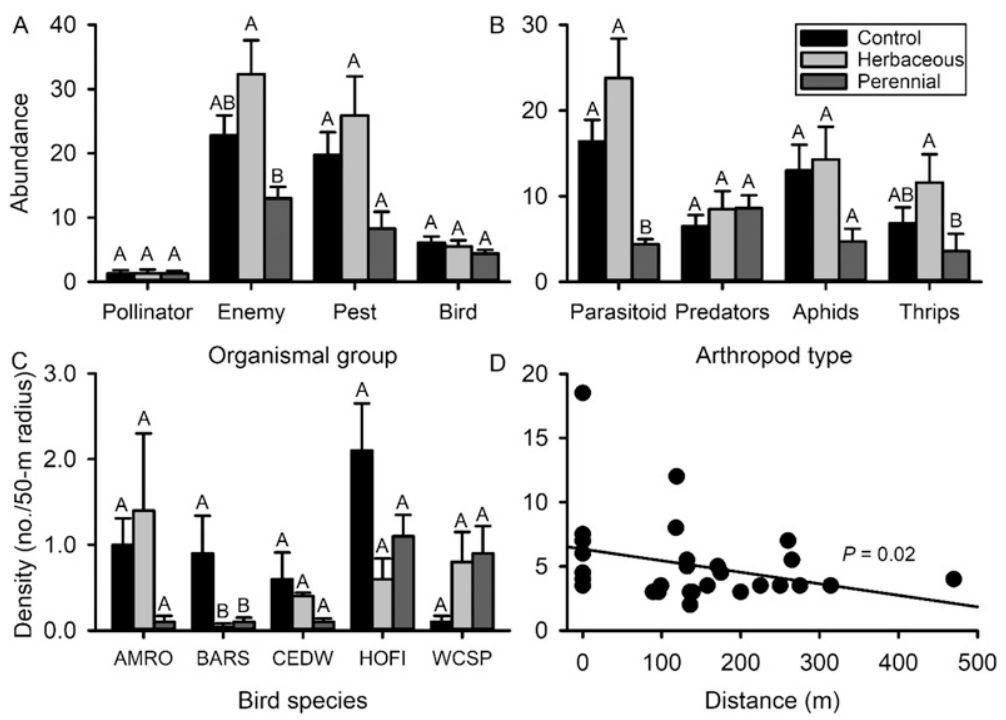

Fig. 2. Average number of organisms per border vegetation treatment (control, herbaceous, and woody perennial) adjacent to nine commercial highbush blueberry fields evaluated in western Washington in 2017. Letters indicate statistical differences using a Tukey's honestly significance test for multiple comparisons with $\alpha=0.05$ and represent comparisons between treatment within organismal groups. (A) Average number of pollinators (visitations/bush/min), natural enemies (no./30-s vacuuming; includes parasitic wasps and predators including rove beetles, carabids, lacewings, ladybird beetles), pests (no./30-s vacuuming; includes thrips and aphids), and birds per $50-\mathrm{m}$ radius point count by border treatment. (B) Average number of parasitoids/parasitic wasps, predators, aphids, and thrips by border treatment (no./30-s vacuuming). (C) Average number of birds by species per $50-\mathrm{m}$ radius point count per border treatment (AMRO = american robin, BARS = barn swallow, CEDW = cedar waxwing, HOFI = house finch, WCSP = white-crowned sparrow). (D) Total wild bird density (birds $/ 50-\mathrm{m}$ radius point) vs. distance to closest seminatural habitat type such as hedge or forest plot (conditional $R^{2}=0.18$, marginal $R^{2}=0.098$ ). Bars represent $\mathrm{SE} ; 1 \mathrm{~m}=3.2808 \mathrm{ft}$.

reservoirs were determined by searching the U.S. Geological Survey (USGS) Wildlife Health Information Sharing Partnership Event Reporting System [WHISPers (USGS, 2020)] and referencing Smith et al. (2020). Finally, the distance from each survey point center to nearest natural/ seminatural habitat (e.g., tree rows and forest patches) was measured using a geographic information system (ArcGIS version 10.2; ESRI, Redlands, CA).

Data ANAlysis. Data were analyzed using Program R ( $\mathrm{R}$ Core Team; R Foundation for Statistical
Computing, Vienna, Austria). A generalized linear mixed model (GLMMs) was implemented in the lme 4 package to analyze the effect of border vegetation treatment on pollination activity (Bates et al., 2015). Plant productivity (i.e., yield, berry weight, and seed number) data were analyzed using the agricolae statistical package (De Mendiburu, 2020). Cultivar and cultivar interactions were assessed for and results were combined across cultivars because no effect of cultivar was detected. GLMMs were also used to analyze the effect of border vegetation treatment on density of nonpollinator arthropods (i.e., natural enemies and pests), birds, and on the impact of distance to closest seminatural or natural habitat on total bird density using the glmmTMB package in $\mathrm{R}$ (Magnusson et al., 2020). Treatment was considered as a fixed effect for density of nonpollinating arthropods, total birds, and focal bird species. Distance to natural habitat was considered a fixed effect for total density of birds. Arthropod density was modeled using time nested within site to account for repeated visits to the same site over time. For modeling bird density, point nested within farm was used as a random effect to account for repeated visits. Nonpollinating arthropod, total bird, and focal bird species data were over dispersed, so a negative binomial distribution was used. We first tested for an impact of treatment on nonpollinating arthropods and birds by comparing models with a fixed treatment term to one without treatment, using a likelihood ratio test. The significance level was set at 0.05 for all data and a Tukey's honestly significance test was used for multiple comparisons. 


\section{Results}

Pollinator activity. Only honeybee and bumble bee (Bombus sp.) pollinators were observed pollinating highbush blueberry blossoms. No significant treatment differences were observed for pollinator activity, and there was no significant interaction between honeybee and bumble bee visitation (Fig. 2, Tables 2 and 3 ).

Plant productivity. No differences were observed across treatments for estimated yield, berry weight, and seed number $(P=0.71,0.34$, and 0.69 , respectively). Estimated yield was $12.1 \mathrm{lb} /$ plant for the control and woody perennial border treatments and $14.6 \mathrm{lb} /$ plant for the herbaceous border treatment. Average berry weight was $1.4,1.3$, and $1.3 \mathrm{~g} /$ berry for the woody perennial, herbaceous, and control border treatments, respectively. Seed number/berry averaged 32,34 , and 38 seeds for the woody perennial, herbaceous, and control border treatments, respectively.

Abundances of natural ENEMIES AND PEST ARTHROPOD SPECIES. We detected few differences in natural enemy and pest arthropod abundances by border type (Fig. 2A and B, Tables 2-4). Natural enemies had greater abundances in herbaceous borders compared with woody perennial borders $(P=0.036)$, but natural enemy abundance did not differ between control borders and either treatment $[P=0.35$ and 0.45 (Fig. 2A)]. Parasitic wasps had the lowest abundance in woody perennial borders $[P<0.0001$ for both woody perennial-control and woody perennial-herbaceous comparisons (Fig. 2B)], but parasitic wasp abundances were similar in control and herbaceous borders $(P=0.29)$. We did not detect differences in arthropod predator abundances by border type $[P=0.91$, 0.45 , and 0.77 (Fig. 2B)]. Similarly, pest arthropods had similar total abundances between treatments $[P=0.99$, 0.19 , and 0.18 (Fig. 2A)], mirrored by results for aphids for which there were no differences observed by treatment type $[P=0.96,0.12$, and 0.078 (Fig. $2 \mathrm{~B})$ ]. Thrips, on the other hand, had higher abundances in herbaceous borders compared with woody perennial borders $[P=0.016$ (Fig. $2 \mathrm{~B}$ )], but abundances were similar between other treatment types $(P=0.60$ and 0.17$)$.
No SWD were collected using either sampling method. SWD populations in the PNW in 2017 were the lowest since they first invaded the state in 2009. Therefore, no investigations into SWD habitat use could be conducted.

Avian assessments. Border vegetation did not impact wild bird densities (Fig. 2C, Tables 2-4). Barn Swallows (Hirundo rustica) were the only species in which we detected a difference in densities between treatments (all other focal species $P>0.063)$. Barn Swallows had the highest densities in control sites compared with both herbaceous $(P=$ $0.024)$ and woody perennial sites $(P=0.032)$. Total wild bird density was inversely related to distance to natural/seminatural habitat $[\beta=$ $-0.0018 \pm 0.0007( \pm \mathrm{SE}) ; P=0.02$; conditional $R^{2}=0.18$, marginal $R^{2}=$ 0.098 (Fig. 2D)].

\section{Discussion}

Border treatments evaluated in this study had negligible impacts on most of the measured variables, including commercial highbush blueberry production metrics. For example, pollinator visitations, yield, average berry weight, and seed number did not differ due to border vegetation. Another finding in this study was that arthropod abundances were low compared with other studies (Blaauw and Isaacs, 2014, 2015). Bird densities were similar between treatments, with the exception of insectivorous barn swallows, but this did not appear to impact fruit yields. These data indicate that the border vegetation treatments we evaluated adjacent to commercial highbush blueberry fields in the PNW provided similar multifunctional effects with regards to pollination and biological control. Further, our data suggest none of these border treatments negatively impacted highbush blueberry production, and some interesting general trends were observed.

Border vegetation appeared to influence some of the arthropod species observed, with herbaceous border treatments sometimes exhibiting greater abundances of arthropods (Fig. 2A and B, Table 2). This mirrors work by Blaauw and Isaacs (2014, 2015 ) in Michigan where they found that diverse border habitats resulted in greater arthropod diversity, and in their case, a greater number of beneficial arthropods than pests. We found that herbaceous borders contained more natural enemies $[32.3 \pm 5.3$ (mean $\pm \mathrm{SE})$ ], probably driven by parasitic wasps $(23.8 \pm 4.6)$, compared with woody perennial borders. Herbaceous borders had similar abundances compared with control sites. The greater number of parasitic wasps in herbaceous borders was potentially due to an increase in nectar or pollen resources. Flowers attract parasitic wasps and boost oviposition and longevity (Wäckers and van Rijn, 2012). However, thrip numbers were also greater in the herbaceous border compared with the woody perennial border (Fig. 2B, Table 2), suggesting they also were responding to presence of pollen, on which they feed (Grinfield, 1959). Fluctuations in numbers of parasitic wasps within each border more closely mirrored that of aphid populations, representative of the cyclical nature of biological control systems (data not presented; Murdoch et al., 1985). Therefore, we infer that the higher numbers of aphids increased parasitic wasp activity and further increased their overall abundances.

We observed cyclical declines in arthropod abundances in all border treatments that coincided with insecticide applications (data not presented). Cyclical declines in arthropods were observed in both the woody perennial and herbaceous borders where plant height would likely intercept pesticide drift. Therefore, the overall low arthropod abundance in our study was likely influenced by SWD insecticide applications, which growers apply regardless of SWD populations in their fields (DeFrancesco et al., 2020). Furthermore, while the year in which the study was conducted was highly unusual given the absence of SWD in the overall region, SWD insecticide applications were still applied due to the zero tolerance for larvae in fresh market fruit. The most effective insecticides have 5- to 7-d residual activity against SWD; so many growers use a 7 -d spray schedule, commonly alternating between pyrethroid and organophosphate insecticides.

The plants in our borders included few dicotyledonous flowering species (data not presented). Even in our herbaceous treatment, the bloom 
Table 2. Average number of pollinators (honeybees and bumble bees), natural enemies, pest arthropods, and wild birds by border treatment type adjacent to highbush blueberry farms in northwest Washington in 2017 . Border vegetation treatments included woody perennial vegetation, herbaceous vegetation, and a control of medium-height grasses. Cultivars surveyed were pooled and included Duke, Draper, and Liberty. Data are presented as means \pm SE. Treatment $P$ value indicates result from Likelihood Ratio Tests (LRT) comparing a model with a treatment effect to a null model with treatment removed.

\begin{tabular}{|c|c|c|c|c|}
\hline & \multicolumn{3}{|c|}{ Border treatment $($ mean $\pm \mathrm{SE})$} & \multirow[b]{2}{*}{ Treatment $(\text { LRT } P)^{\mathrm{z}}$} \\
\hline & Control & Herbaceous & Woody perennial & \\
\hline $\begin{array}{l}\text { Pollinators }^{\mathrm{y}} \\
\text { (honeybees and bumble bees) }\end{array}$ & $1.3 \pm 0.5$ & $1.3 \pm 0.6$ & $1.3 \pm 0.4$ & \\
\hline Natural enemies & $22.8 \pm 3.1 \mathrm{ab}^{\mathrm{x}}$ & $32.3 \pm 5.3 \mathrm{a}$ & $13.0 \pm 1.8 b$ & 0.063 \\
\hline Parasitic wasps & $16.4 \pm 2.5 \mathrm{a}$ & $23.8 \pm 4.6 \mathrm{a}$ & $4.4 \pm 0.59 \mathrm{~b}$ & 0.0009 \\
\hline Predators & $6.5 \pm 1.3 \mathrm{a}$ & $8.5 \pm 2.1 \mathrm{a}$ & $8.6 \pm 1.5 \mathrm{a}$ & 0.52 \\
\hline Thrips & $6.8 \pm 1.9 \mathrm{ab}$ & $11.6 \pm 3.3 \mathrm{a}$ & $3.6 \pm 2.0 \mathrm{~b}$ & 0.087 \\
\hline \multicolumn{5}{|l|}{ Birds $^{\mathrm{w}}$} \\
\hline Total bird density & $6.1 \pm 0.96 \mathrm{a}$ & $5.5 \pm 0.98 a$ & $4.4 \pm 0.58 \mathrm{a}$ & 0.38 \\
\hline American robin & $1.0 \pm 0.31 \mathrm{a}$ & $1.4 \pm 0.9 \mathrm{a}$ & $0.1 \pm 0.07 \mathrm{a}$ & 0.086 \\
\hline Barn swallow & $0.9 \pm 0.44 \mathrm{a}$ & $0.04 \pm 0.04 \mathrm{~b}$ & $0.1 \pm 0.05 \mathrm{~b}$ & 0.017 \\
\hline
\end{tabular}

${ }^{\mathrm{z}} \mathrm{LRT}=$ likelihood ratio test.

${ }^{\mathrm{y}}$ Averages for the pollinator data are per border treatment for the three replicate sites with data collected on 3 separate days; averages for other arthropods are per treatment for the three replicate sites with data collected weekly over a l6-week period.

${ }^{\mathrm{x}}$ Means with the same letter within a column are not different due to treatment at $\alpha=0.05$ using a Tukey's honestly significance test for multiple comparisons.

wAverages for the avian data are per treatment for the three replicate sites with data collected on 2 separate days.

Table 3. Statistical results from generalized linear mixed effects models analyzing the effects of border vegetation treatments on pollinators, natural enemies, and pest arthropods, and wild bird abundances in and adjacent to highbush blueberry fields in northwestern Washington in 2017. Numbers in the table show model coefficients, standard error in parentheses, and associated probability values. The control treatment was used as the reference group, so probability values shown for herbaceous and woody perennial sites compare differences between treatment and the control. The control treatment probability value indicates a difference between the control sites and at least one treatment.

\begin{tabular}{|c|c|c|c|c|c|c|}
\hline \multirow[b]{2}{*}{ Species } & \multicolumn{6}{|c|}{ Model coefficients (SE) } \\
\hline & Control & $P$ & Herbaceous & $P$ & Woody perennial & $P$ \\
\hline Pollinators & $1.66(0.78)$ & 0.38 & $1.22(0.84)$ & 0.12 & $3.36(0.71)$ & 0.08 \\
\hline Parasitic wasps & $2.41(0.21)$ & $<0.001$ & $0.26(0.29)$ & 0.41 & $-1.10(1.13)$ & 0.01 \\
\hline Predators & $1.03(0.19)$ & $<0.001$ & $0.029(0.27)$ & 0.92 & $0.60(0.27)$ & 0.07 \\
\hline \multicolumn{7}{|l|}{ Pest arthropods } \\
\hline \multicolumn{7}{|l|}{ Birds } \\
\hline Total wild bird density & $1.79(0.19)$ & $<0.001$ & $-0.11(0.24)$ & 0.67 & $-0.32(0.25)$ & 0.25 \\
\hline American robin & $-0.28(0.65)$ & 0.67 & $-1.24(0.87)$ & 0.21 & $-1.94(0.916)$ & 0.09 \\
\hline Barn swallow & $-0.85(0.65)$ & 0.20 & $-3.07(1.09)$ & 0.04 & $-2.38(0.96)$ & 0.06 \\
\hline Cedar waxwing & $-1.18(0.78)$ & 0.14 & $-0.78(1.04)$ & 0.49 & $-2.57(1.29)$ & 0.10 \\
\hline
\end{tabular}

period did not extend the entire production season and most flowering species were members of the Asteraceae family (data not presented). Bloom of the three highbush blueberry cultivars in our study occurred in April and May, while insect abundance increased in mid-June. The limited number of flowering species and bloom period may explain why our border treatments did not increase pollination. In contrast, Gibbs et al. (2016) reported a positive correlation between seminatural habitats and wild bee abundance in both Michigan and western British Columbia. Blaauw and Isaacs $(2014,2015)$ used purposeful plantings of flowering plants with an extended bloom period in their studies in Michigan.
Regional bee communities differ between Michigan and British Columbia highbush blueberry fields, with large-bodied bumble bees being more prevalent in the wild bee community in British Columbia (Gibbs et al., 2016). British Columbia is like western Washington, and different plant species are likely needed in border vegetation to maximize their 
Table 4. Statistical results from Tukey's honestly significance test for multiple comparisons of border vegetation treatments on pollinator, natural enemies, and pest arthropods, and wild bird abundances in and adjacent to highbush blueberry fields in northwestern Washington in 2017 . Numbers in the table show estimated differences and associated probability values.

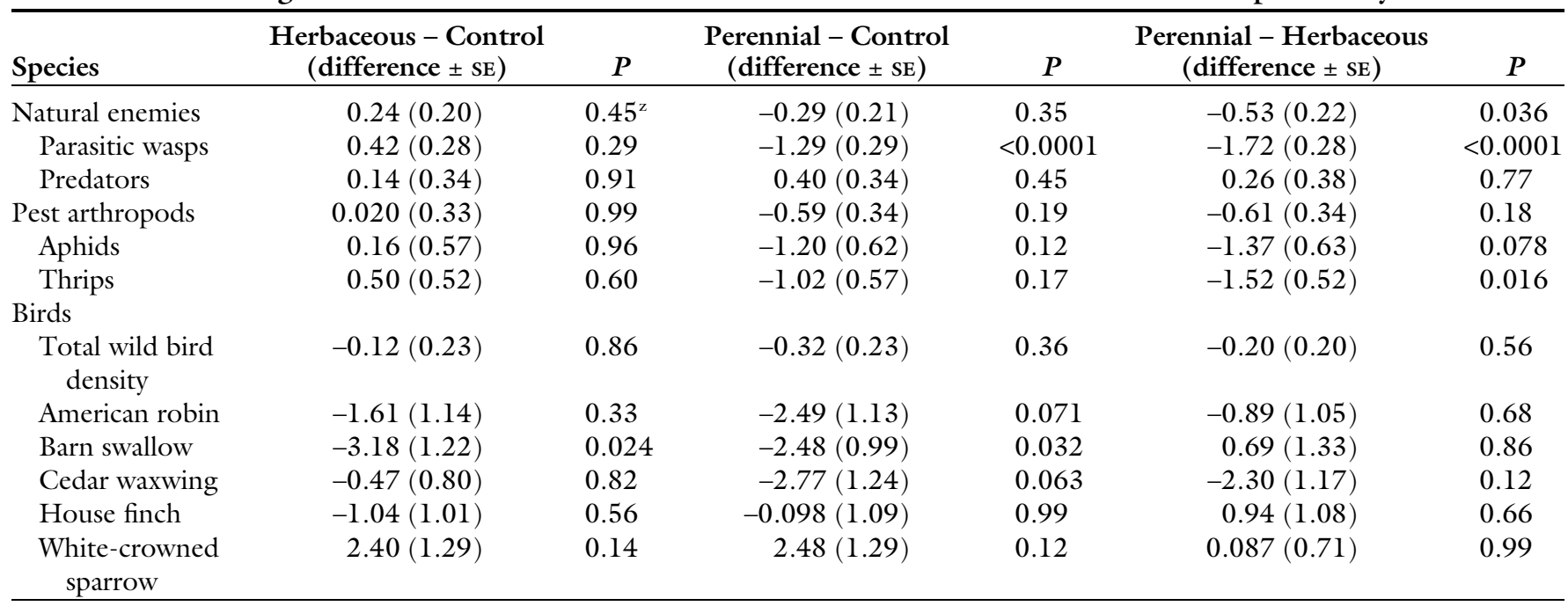

${ }^{\mathrm{z}}$ Probability values $<0.05$ were considered statistically significant.

potential benefits on pollination services in the PNW. For example, the use of multiple, carefully selected flowering species that provide food resources and habitat for pollinators could benefit highbush blueberry pollination and other production variables in the PNW. Yet, many growers in the PNW and elsewhere have expressed reluctance to intentionally plant flowering species for enhancement of pollination services due to the perceived costs, maintenance, and skepticism of their potential beneficial effects on crop production (Garbach and Long, 2017). Preservation or maintenance of natural habitats may be an alternative to intentional plantings of flowering species if the habitat is available.

To better understand the impact of border treatments on bird densities, we selected wild bird focal species that prior research suggests are beneficial insectivores, beneficial carnivores, or crop pests and were known to be common in the study region (Smith et al., 2019). Barn swallows had the highest densities in control sites that had limited vegetation, which is unsurprising given their known preference for open foraging areas (Brown and Brown, 1999). The barn swallow diet is almost exclusively flying insects, including aphids, cicadas (superfamily Cicadoidea), leafhoppers (family Cicadellidae), and moths and butterflies (order Lepidoptera) (Bael, 1918), suggesting they could be beneficial to highbush blueberry production. The only species that consumes primarily fruit, the cedar waxwing (Bombycilla cedrorum), had the lowest densities in sites with woody perennial border vegetation, but differences were not significant. This was surprising given the known association of cedar waxwings with trees and shrubs (Witmer et al., 2020), but this likely was due to bird deterrence mechanisms used on the farms [cannons and "bird scarers" (Olimpi et al., 2020)]. Further, prior research has suggested that singlespecies tree rows are less effective at bolstering bird abundances compared with diverse hedges and riparian areas (Heath et al., 2017). Only a few american crows and red-tailed hawks were observed across the sites, precluding statistical analyses. Surprisingly, no european starlings were observed in 2017 within treatment plots. European starlings are known to damage fruit crops and reach high densities in agricultural systems (Somers and Morris, 2002), but they are also known to exhibit large seasonal and annual fluctuations in flock size and habitat use (Fischl and Caccamise, 1985).

We observed higher total wild bird densities as the distance to natural habitat decreased, consistent with prior research (Boesing et al., 2017; Maas et al., 2015). A growing body of literature has linked increased avianmediated pest control services with decreasing proximity to natural habitat (Boesing et al., 2017). However, other studies have documented increased fruit damage by wild birds toward the edges of plots (Olimpi et al., 2020; Somers and Morris, 2002). To elucidate the net effects of wild birds on highbush blueberry yields, more data are needed on wild bird diet and net yield when birds are excluded. Further, though we found evidence for all focal species to harbor deadly human enteric pathogens in our literature review (Table 1; Smith et al., 2020), it is unclear how great a risk each poses to food safety of blueberries because few data exist to generate robust risk assessments (Smith et al., 2020). Future research should continue to evaluate risks and benefits of different borders on wild bird communities, while focusing efforts on testing native songbird species for human enteric pathogens, estimating pathogen survival in bird droppings on produce, and considering wild bird/produce contact rates to elucidate likely food safety risk (Feare et al., 1999; Smith et al., 2020).

Pollination limitations and SWD management remain challenges for commercial highbush blueberry production in the PNW. While our sample size may have hindered our ability to detect significant treatment effects, trends indicate that the woody perennial and herbaceous border vegetation treatments adjacent to 
commercial highbush blueberry fields provided similar pollination, biological control, and highbush blueberry production effects compared with control borders. An added benefit of woody perennial and herbaceous borders is their contribution to reducing pesticide drift, deterring trespassers, and serving as windbreaks. While herbaceous border vegetation and control plots sometimes were associated with greater abundances relative to perennial border plots, it is unclear what risks or benefits this may pose for commercial highbush blueberry. The low abundance of arthropods in our study was likely influenced by current intensive SWD management programs. To enhance pollination and biological control in PNW highbush blueberry systems, future research should investigate use of different border plant species that could stimulate pollinator foraging in highbush blueberry, promote regional wild pollinator communities, and promote natural enemies. Furthermore, investigations should be done in tandem with research that aims to reduce growers' reliance on intense SWD insecticide programs to manage this important pest.

\section{Literature cited}

Anderson, A., C.A. Lindell, K.M. Moxcey, W.F. Siemer, G.M. Linz, P.D. Curtis, J.E. Carroll, C.L. Burrows, J.R. Boulanger, K.M.M. Steensma, and S.A. Shwiff. 2013. Bird damage to select fruit crops: The cost of damage and the benefits of control in five states. Crop Prot. 52:103-109, doi: 10.1016/j.cropro.2013.05.019.

Bael, F.E.L. 1918. Food habits of the swallows, a family of valuable native birds. U.S. Dept. Agr. Bull. 619:1-28.

Bates, D., M. Maechler, B. Bolker, and W. Walker. 2015. Fitting linear mixed-effects models using lme4. J. Stat. Softw. 67:1-48.

Billerman, S.M., P.G. Keeney, P.G. Rodewald, and T.S. Schulenberg. 2020. Birds of the world. 3 Sept. 2020. <https://birdsoftheworld.org/bow/ home $>$.

Blaauw, B.R. and R. Isaacs. 2014. Flower plantings increase wild bee abundance and the pollination services provided to a pollination-dependent crop. J. Appl Ecol. 51:890-898, doi: 10.1111/13652664.12257.

Blaauw, B.R. and R. Isaacs. 2015. Wildflower plantings enhance the abun- dance of natural enemies in adjacent highbush blueberry fields. Biol. Control 91:94-103, doi: 10.1016/j.biocontrol. 2015.08 .003

Boesing, A.L., E. Nichols, and J.P. Metzger. 2017. Effects of landscape structure on avian-mediated insect pest control services: A review. Landsc. Ecol. 32:931-944, doi: 10.1007/s10980-0170503-1.

Brown, C.R. and M.B. Brown. 1999. Barn swallow (Hirundo rustica), version 2.0. In: A.F. Poole (ed.). Birds of the world. Cornell Lab Ornithol., Ithaca, NY. doi: $10.2173 /$ bna.452.

Courcelles, D.M., L. Button, and E. Elle. 2013. Bee visit rates vary with floral morphology among highbush blueberry cultivars (Vaccinium corymbosum L.). J. Appl. 137:693-701, doi: 10.1111/jen.12059.

De Mendiburu, F. 2020. Package agricolae: Statistical procedures for agricultural research. $\mathrm{R}$ package version 1.3-3 16 Nov. 2020. <https://CRAN.Rproject.org $/$ package $=$ agricolae $>$.

DeFrancesco, J., B. Edmunds, and N. Bell. 2020. Highbush blueberry pests: Highbush blueberry-spotted wing drosophila (SWD). In: Pacific Northwest insect management handbook. 11 Feb. 2020. <http://pnwhandbooks.org/ insect/small-fruit/highbush blueberry>.

DeVetter, L.W., S. Watkinson, R. Sagili, and T. Lawrence. 2016. Honey bee activity in northern highbush blueberry differs across growing regions in Washington State. HortScience 51:1228-1232, doi: 10.21273/HORTSCI10934-16.

Feare, C.J., M.F. Sanders, R. Blasco, and J.D. Bishop. 1999. Canada goose (Branta canadensis) droppings as a potential source of pathogenic bacteria. J. R. Soc. Promot. Health 119:146-155, doi: 10.1177/146642409911900303.

Fischl, J. and D.F. Caccamise. 1985. Influence of habitat and season on foraging flock composition in the european starling (Sturnus vulgaris). Oecologia 67:532539, doi: 10.1007/BF00790025.

Garbach, K. and R. F. Long. 2017. Determinants of field edge habitat restoration on farms in California's Sacramento Valley. J. Environ. Manage. 189:134-141, doi: 10.1016/j.jenvman.2016.12.036.

Gerdeman, B., L. Tanigoshi, and G.H. Spitler. 2011. Spotted wing drosophila (SWD) monitoring, identifying, and fruit sampling. Washington State Univ. Ext. FS049E.

Gibbs, J., E. Elle, K. Bobiwash, T. Haapalainen, and R. Isaacs. 2016. Contrasting pollinators and pollination in native and non-native regions of highbush blueberry production. PloS One. 11(7), doi: 10.1371/journal.pone.0158937.

Grinfield, E.K. 1959. The feeding of thrips (Thysanoptera) on pollen of flowers and the origin of asymmetry in their mouthparts. [In Russian]. Entomol. Obozr. 38:798-804.

Gorski, L., C.T. Parker, A. Liang, M.B. Cooley, M.T. Jay-Russell, A.G. Gordus, E.R. Atwill, and R.E. Mandrell. 2011. Prevalence, distribution, and diversity of Salmonella enterica in a major produce region of California. Appl. Environ. Microbiol. 77:2734-2748, doi: 10.1128/ AEM.02321-10.

Hald, B., M.N. Skov, E.M. Nielsen, C. Rahbek, J.J. Madsen, M. Waino, M. Chriel, S. Nordentoft, D.L. Baggesen, and M. Madsen. 2016. Campylobacter jejuni and Campylobacter coli in wild birds on Danish livestock farms. Acta Vet Scand. 58:11, doi: 10.1186/s13028016-0192-9.

Haviland, D., J. Caprile, S. Rill, K. Hamby, and J. Grant. 2016. Phenology of spotted wing drosophila in the San Joaquin Valley varies by season, crop and nearby vegetation. Calif. Agr. 70(1):2431, doi: 10.3733/ca.v070n01p24.

Heath, S.K., C.U. Soykan, K.L. Velas, R. Kelsey, and S.M. Kross. 2017. A bustle in the hedgerow: Woody field margins boost on farm avian diversity and abundance in an intensive agricultural landscape. Biol. Conserv. 212:153-161, doi: 10.1016/ j.biocon.2017.05.031.

Isaacs, R., J. Gibbs, and E. May. 2016. Invest in pollination for success with highbush blueberries. 15 Sept. 2020. <https://www.canr.msu.edu/news/ invest_in_pollination_for_success_with_ highbush_blueberries $>$.

Kobayashi, H., M. Kanazaki, E. Hata, and M. Kubo. 2009. Prevalence and characteristics of eae- and stx-positive strains of Escherichia coli from wild birds in the immediate environment of Tokyo Bay. Appl. Environ. Microbiol. 75:292-295, doi: 10.1128/AEM.01534-08.

Maas, B., T. Tscharntke, S. Saleh, D.D. Putra, and Y. Clough. 2015. Avian species identity drives predation success in tropical cacao agroforestry. J. Appl. Ecol 52:735-743, doi: 10.1111/1365-2664. 12409 .

Magnusson, A., H. Skaug, A. Nielsen, C. Berg, K. Kristensen, M. Maechler, K. van Bentham, B.M. Bolker, N. Sadat, D. Lüdecke, R. Length, J. O'Brien, and M. Brooks. 2020. glmmTMB: Generalized linear mixed models using template model builder. R package version 1.0.2.1. 
16 Nov. 2020. <https://CRAN.Rproject.org $/$ package $=$ glmmTMB $>$.

Murdoch, W., J. Chesson, and P. Chesson. 1985. Biological control in theory and practice. Amer. Nat. 125:344-366.

Nielsen, E.M., M.N. Skov, J.J. Madsen, J. Lodal, J.B. Jespersen, and D.L. Baggesen. 2004. Verocytotoxin-producing Escherichia coli in wild birds and rodents in close proximity to farms. Appl. Environ. Microbiol. 70:6944-6947, doi: 10.1128/ AEM.70.11.6944-6947.2004.

Olimpi, E.M., K. Garcia, D. Gonthier, K.T. De Master, A. Escheverri, C. Kremen, A.R. Sciligo, W.E. Snyder, E.E. Wilson-Rankin, and D.S. Karp. 2020. Shifts in species interactions and farming contexts mediate net effects of birds in agroecosystems. Ecol. Appl. 30(5):e02115, doi: 10.1002/ eap. 2115 .

Shave, M.E., S.A. Shwiff, J.L. Elser, and C.A. Lindell. 2018. Falcons using orchard next boxes reduce fruit-eating bird abundances and provide economic benefits for a fruit-growing region. J. Appl. Ecol. 55:2451-2460, doi: 10.1111/13652664.13172 .

Skov, M.N., J.J. Madsen, C. Rahbek, J. Lodal, J.B. Jespersen, J.C. Jorgensen, H.H Dietz, M. Chriel, and D.L. Baggesen. 2008. Transmission of Salmonella between wildlife and meat-production animals in Denmark. J. Appl. Microbiol. 105:1558-1568, doi: 10.1111/j.13652672.2008.03914.x.

Smith, O.M., C.M. Kennedy, J.P. Owen, T. Northfield, C.E. Latimer, and W.E.
Snyder. 2019. Highly diversified croplivestock farming systems reshape wild bird communities. Ecol. Appl. 30:e02031, doi: 10.1002/eap.2031.

Smith, O.M., W.E. Snyder, and J.P. Owen. 2020. Are we overestimating the risk of enteric pathogen spillover from wild birds to humans? Biol. Rev. 95:652679, doi: 10.1111/brv.12581.

Somers, C.M. and R.D. Morris. 2002. Birds and wine grapes: Foraging activity causes small-scale damage patterns in single vineyards. J. Appl. Ecol 39:511523, doi: 10.1046/j.1365-2664.2002. 00725.x.

Symondson, W.O.C., K.D. Sunderland, and M.H. Greenstone. 2002. Can generalist predators be effective biocontrol agents? Annu. Rev. Entomol. 47:561594, doi: 10.1146/annurev.ento.47. 091201.145240 .

Tochen, S., V.M. Walton, and J.C. Lee. 2016. Impact of floral feeding on adult Drosophila suzukii survival and nutrient status. J. Pest Sci. 89:793-802, doi: 10.1007/s10340-016-0762-7.

Tuell, J.K., A.K. Fiedler, D. Landis, and R. Isaacs. 2008. Visitation by wild and managed bees (Hymenoptera: Apoidea) to eastern US native plants for use in conservation programs. Environ. Entomol. 37:707-718, doi: 10.1603/0046$225 \mathrm{x}(2008) 37[707$ :vbwamb]2.0.co;2.

U.S. Department of Agriculture, National Agricultural Statistics Service. 2020.
Noncitrus fruits and nuts 2019 summary. 28 Aug. 2020. <https://usda.library. cornell.edu/concern/publications / zs $25 \times 846 c>$.

U.S. Geological Survey. 2020. Wildlife Health Information Sharing Partnership Event Reporting System (WHISPers). 25 Aug. 2018. <http://www.nwhc.usgs. gov $/$ whispers $/>$.

Wäckers, F.L. and P.C. van Rijn. 2012. Pick and mix: Selecting flowering plants to meet the requirements of target biological control insects, p. 139-165. In: G.M. Gurr, S.D. Wratten, and W.E. Snyder (eds.). Biodiversity and insect pests: Key issues for sustainable management. Wiley-Blackwell, Hoboken, NJ. doi: 10.1002/9781118231838.ch9.

Wilman, H., J. Belmaker, J. Simpson, C. de la Rosa, M.M. Rivadeneira, and W. Jetz. 2014. EltonTraits 1.0: Species-level foraging attributes of the world's birds and mammals. Ecology 95:2027-2027, doi: 10.1890/13-1917.1.

Witmer, M.C., D.J. Mountjoy, and L. Elliott. 2020. Cedar Waxwing (Bombycilla cedrorum), version 1.0. In: A.F. Poole (ed.). Birds of the world. Cornell Lab Ornithol., Ithaca, NY. doi: 10.2173/ bow.cedwax.01. 